\title{
Factors Influencing Economic Losses due to Milk Fever in Dairy Farms
}

\author{
V. Senthilkumar* \\ Department of Animal Husbandry Economics, Tamil Nadu Veterinary and Animal Sciences \\ University, Veterinary College and Research Institute, Namakkal-637 002, India \\ *Corresponding author
}

\section{A B S T R A C T}

\section{Keywords}

Milk fever,

Metabolic Diseases and Multiple linear function

\section{Article Info}

Accepted:

15 July 2020

Available Online:

10 August 2020
Milk fever is the common disease and one among the important metabolic disorder in lactating dairy animals. It is an afebrile hypocalcaemic disease of cattle usually associated with immediately after parturition and initiation of lactation. Milk fever is a metabolic disease occurring in dairy animals during parturient period and management is economically most important, as it results in not only reduction in milk production but also loss of animals. For the study, 83 milk fever affected dairy animals (both cows and buffaloes) were selected through multistage random sampling technique from Namakkal and Karur districts of Tamil Nadu. Data were collected from the respondent farmers through personal interviews, using pretested interview schedule. A multiple linear regression function model was fitted to study the factors influencing economic loss due to milk fever in dairy farms. The variables viz., late stage of lactation, season summer, season winter, number of days illness and milk yield included to explain the variations in the losses due to milk fever were found to be significant at one per cent level $(\mathrm{P} \leq 0.01)$. The other factor mid stage of lactation was found to be significant and negative at five per cent level $(\mathrm{P} \leq 0.05)$. The coefficient of average daily milk yield per animal (5.703) indicated that the economic loss due to milk fever would increase by Rs.5.703 per affected animal as the average daily milk yield of the animal increases by one litre of milk from its mean level.

\section{Introduction}

The livestock sector particularly dairy farming plays a significant role in securing the livelihood of rural farmers by providing income and employment generation in rural areas. However, this sector is facing several disease problems due to introduction of exotic germ plasm for higher productivity and changing global climate which cause huge economic loss resulting from mortality and low productivity of animals (Singh and Shivprasad, 2008). Livestock diseases particularly metabolic disorders in dairy animals cause reduction in production efficiency leading to severe economic losses (John Christy and Thirunavukkarasu, 2006). Milk fever is an afebrile hypocalcaemic disease of cattle usually associated with immediately after parturition and initiation of lactation. This disease has been known by a number of terms namely parturition paresis, 
milk fever, parturient apoplexy, eclampsia and paresis peurperalis (Littledike et al., 1981). Further, increasing production of milk after calving places an enormous demand for glucose and minerals at a time when feed intake would not have reached its peak, leading to draining of glucose and calcium from the blood and leaving the milch animal's metabolism under severe stress, as transitions to lactation (Bethard and Smith, 1998). Clinical hypocalcaemia can occur before, during or after calving (Bar and Ezra, 2005). Milk fever is a metabolic disease occurring in dairy animals during parturient period and management is economically most important, as it results in not only reduction in milk production but also loss of animals (Thirunavukkarasu et al., 2010). Analyzing the various causative factors involved in milk fever is important to help in understanding the effective management and prevention of this disease, which can aid in losses to be avoided in dairy farming. Keeping the above facts in view, this study was conducted in Karur and Namakkal districts of Tamil Nadu State.

\section{Materials and Methods}

For the study, 83 milk fever affected female bovines were selected through multistage random sampling technique from Namakkal and Karur districts. Affected dairy animals were identified by case registers of veterinary dispensaries and clinics of Veterinary College and Research Institute, Namakkal and practicing private veterinary doctors in both districts. This study is based on the primary data collected through personal interviews with the farmers using pre tested interview schedule.

The data collected from the sample respondents included information on size of animal holdings, breed, parity, stage of lactation, frequency of occurrence, stage of calving, feeding practices, number of days illness, system of rearing, milk yield, season of disease occurrence and production losses were also collected.

A multiple linear regression function of the following form was fitted to study the factors influencing economic loss due to milk fever in dairy farms.

$Y_{j}=a+b_{1} X_{1}+b_{2} X_{2}+b_{3} X_{3}+b_{4} X_{4}+b_{5} X_{5}+$ $b_{6} X_{6}+b_{7} X_{7}+b_{8} X_{8}+b_{9} X_{9}+U_{j}$

Where, $\mathrm{Y}_{\mathrm{j}}=$ Per animal annual economic loss due to milk fever

a, $b_{i}=$ Coefficients to be estimated $\mathrm{U}_{\mathrm{j}}=$ Error term

The description of variables used in multiple linear regression analysis for milk fever in dairy animals is presented in Table 1.

\section{Results and Discussion}

Based on the results of ANOVA, linear regression models were fitted for milk fever to assess the contribution of different factors to the economic loss arising due to milk fever in dairy animals and the results are presented in Table 2.

The coefficient of multiple determination (adjusted $\mathrm{R}^{2}$ ) in the model fitted for milk fever was 0.553, indicating that the model was a good fit and that about 55.30 per cent of the variation in the dependent variable, i.e., economic losses due to Milk fever could be explained by the chosen independent variables. The ' $F$ ' statistic also showed that the fitted regression model was found to be significant.

The variables viz., late stage of lactation, season summer, season winter, number of days illness and milk yield included to explain the variations in the losses due to milk fever 
were found to be significant at one per cent level $(\mathrm{P} \leq 0.01)$. The other factor mid stage of lactation was found to be significant and negative at five per cent level $(\mathrm{P} \leq 0.05)$.

Table.1 Description of variables used in multiple linear regression analysis for milk fever in dairy animals

\begin{tabular}{|c|c|c|c|}
\hline Explanatory variables & Levels & Specifications & $\mathbf{X}_{\mathbf{i}}$ \\
\hline \multirow[t]{2}{*}{ Stage of lactation a } & \multirow{2}{*}{$\begin{array}{l}\text { Early stage; Mid stage; } \\
\text { Late stage }\end{array}$} & 1-if Mid; 0-Otherwise & $\mathrm{X}_{1}$ \\
\hline & & 1-if Late; 0-Otherwise & $\mathrm{X}_{2}$ \\
\hline Breed & $\begin{array}{l}\text { Non-descript; } \\
\text { Crossbred cow / } \\
\text { Graded buffalo }\end{array}$ & $\begin{array}{l}\text { 1-Crossbred Cow/ } \\
\text { Graded Buffalo; 0- } \\
\text { Otherwise }\end{array}$ & $\mathrm{X}_{3}$ \\
\hline Parity (Order of lactation) & Continuous & In number of calving & $\mathrm{X}_{4}$ \\
\hline \multirow[t]{2}{*}{ Season $^{b}$} & \multirow[t]{2}{*}{$\begin{array}{l}\text { Summer; Winter; } \\
\text { Monsoon }\end{array}$} & $\begin{array}{l}\text { 1-if Summer; 0- } \\
\text { Otherwise }\end{array}$ & $\mathrm{X}_{5}$ \\
\hline & & 1-if Winter; 0-Otherwise & $\mathrm{X}_{6}$ \\
\hline Number of days illness & Continuous & In number of days ill & $\mathrm{X}_{7}$ \\
\hline Average daily milk yield & Continuous & Litres per day & $\mathrm{X}_{8}$ \\
\hline Species of dairy animal & Cow; Buffalo & 1-if Cow; 0-Otherwise & $\mathrm{X}_{9}$ \\
\hline
\end{tabular}

${ }^{a}$ reference category: Early lactation; ${ }^{\mathrm{b}}$ reference category: monsoon

Table 2 Regression coefficients of linear models fitted to analyse the factors influencing milk fever in dairy animals

(Dependent variable: Milk fever in dairy animals)

\begin{tabular}{|c|c|}
\hline Variables & Coefficients \\
\hline Constant & $549.537(38.030)$ \\
\hline Breed & $10.642(20.936)$ \\
\hline Order of lactation & $-6.628(6.408)$ \\
\hline Stage of lactation 2 & $-52.410 *(21.228)$ \\
\hline Stage of lactation 3 & $-63.670 * *(23.162)$ \\
\hline Milk yield & $5.703 * *(1.920)$ \\
\hline Season summer & $37.302 * *(11.745)$ \\
\hline Season winter & $-35.621 * *(11.410)$ \\
\hline Number of days illness & $83.974 * *(16.388)$ \\
\hline Species & $-6.211(18.356)$ \\
\hline $\begin{array}{l}\text { Coefficient of multiple } \\
\text { determination (adjusted } \mathbf{R}^{2} \text { ) }\end{array}$ & 0.551 \\
\hline F statistic & 12.292 \\
\hline $\mathbf{N}$ & 83 \\
\hline
\end{tabular}


The coefficient of average daily milk yield per animal (5.703) indicated that the economic loss due to milk fever would increase by Rs.5.703 per affected animal as the average daily milk yield of the animal increases by one litre of milk from its mean level (Thirunavukkarasu et al., 2010). The coefficient of duration of illness (83.974) indicated that as the duration of illness extends by one day from its mean level, the economic losses are liable to increase by Rs.83.97. The coefficient of stage of lactation and coefficient of season were found to be significant and had influence over occurrence of milk fever.

In conclusions the results of this study, as it analyzing the factors involved in milk fever dairy farms, will aid the researchers, planners and policy makers to design suitable policy decisions and appropriate preventive measures to combat this disease. Creating awareness about the important of this disease and nutritive values of various commonly used feed ingredients at field level through extension programmes to minimize this disease loss.

\section{References}

Bar, D and E. Ezra. 2005. Effects of common calving diseases on milk production in high-yielding dairy cows. Israel Journal of Veterinary Medicine, 60(4):
34-42.

Bethard, G and J.F. Smith. 1998. Controlling milk fever and hypocalcaemia in dairy cattle: use of Dietary Cation-Anion Difference (DCAD) in formulating dry cow rations. Technical report 31, Agricultural Experiment Station, Cooperative Extension Service, College of Agriculture and Home Economics, New Mexico State University.

John Christy, $\mathrm{R}$ and M. Thirunavukkarasu. 2006. Emerging importance of animal health economics-a note. Tamil Nadu Journal of Veterinary and Animal Sciences, 2(3): 113-117.

Littledike, E.T., J.W. Young and D.C. Beitz. 1981. Common metabolic diseases of cattle: ketosis, milk fever, grass tetany and downer cow complex. Journal of Dairy Science, 64: 1465.

Singh, B and Shiv Prasad. 2008. Modelling of economic losses due to some important diseases in goats in India. Agricultural Economics Research Review, 21: 297-302.

Thirunavukkarasu, M., G. Kathiravan, A. Kalaikannan and W. Jebarani. 2010. Quantifying economic losses due to milk fever in dairy farms. Agricultural Economics Research Review, 23: 7781.

\section{How to cite this article:}

Senthilkumar, V. 2020. Factors Influencing Economic Losses due to Milk Fever in Dairy Farms. Int.J.Curr.Microbiol.App.Sci. 9(08): 1410-1413. doi: https://doi.org/10.20546/ijcmas.2020.908.161 